\title{
Report of the Trainees Committee
}

The important issues for trainees at the moment are the present manpower initiatives and the new MRCPsych examination.

\section{Manpower}

Both the Collegiate Trainees' Committee (CTC) and Council have rejected the document 'Hospital Medical Staffing': Achieving a Balance. ${ }^{1}$ However the College seems to be in the minority of bodies against the current proposals; other Colleges, the Council of the BMA and the Hospital Junior Staff Committee (HJSC) have supported it. The Special Conference of the HJSC met on 13 December 1987 and supported the proposals by a narrow majority. ${ }^{2}$ With negotiation still continuing it seems unlikely that all the proposals will be implemented by 1 January 1987 .

There are three main reasons why the CTC is against the proposals:

1. Some of the proposals would not easily fit the current psychiatric manpower structure. The proposals are designed for specialities (like medicine and surgery) which have post membership Registrars, whereas in psychiatry Registrars are appointed before Membership.

2. Having Registrar posts divided into District and Regional posts may lead to quite different qualities of training. The CTC would prefer to see one type of post with a certain number earmarked for overseas graduates.

3. The present proposals of the 'Intermediate Level Service Grade' are unacceptable. No other appointment in medicine involves a probation period. The appointment would be made too early (at SHO level). It is a 'service' rather than 'training' grade. Terms and conditions of service are not stated and the only possible promotion is to the Associate Specialist grade. However, security of tenure would be an advance from the present position for maximum part-time clinical assistants: it is therefore a move in the right direction.

Some of the proposals in the document are to be welcomed. Because of that the CTC consider it unfortunate that the proposals had to be accepted or rejected 'as a package', and that little consultation occurred within the profession before the document came out. A better way might have been to have considered draft proposals before definite proposals were made.

It is now becoming clear that these proposals are still being negotiated. For instance, all Registrar contracts may after all be held at Regional Level and the intermediate grade might have education and study leave equivalent to a consultant. ${ }^{2}$

\section{The new MRCPsych examination}

The new examinations will occur for the first time in September 1987. The CTC were represented on the Working
Party which formulated the new examinations. The Committee particularly supported making the preliminary test (to be re-named Part 1 MRCPsych) a more comprehensive examination of clinical skills early in a career.

The CTC is aware that the new examination has implications for trainers as well as trainees. For instance, there is an important need for the examinee to show the examiners that he/she has understood and can apply the principles of a good clinical interview. To do this a trainee needs to receive a training in interviewing skills. This is not at present universally available. This along with other issues was addressed in the 1987 Trainees Forum held in January. This will be submitted to the Bulletin in the near future.

\section{The consultant based service}

The report of the CTC Working Party, written by Dr Rob Poole, was published in last month's Bulletin. A Consultant based service is a service without trainees, run primarily by the Consultant. ${ }^{3}$ The CTC was very concerned that the present model of service for a minority of Consultants would continue to be implemented without the College giving its guidance on the requirements for the ideal service. Happily a Working Party has been set up to consider 'the implications of existing and possible "Consultant based surfaces" and to make recommendations on services, staffing and training'.

\section{Part-time training in psychiatry}

A report giving practical guidance on how to apply for and be appointed to a part-time training post is now available. This is the result of a CTC Working Party (convened by Dr Elaine Arnold), is available from the College and will also be published in the new Inceptors Handbook.

\section{The public image of psychiatry}

This is a major concern of the CTC and the Committee has welcomed the appointment of a public relations firm to advise the College. An immediate result of this was the good media response to the report Alcohol, Our Favourite Drug, which even received coverage in The Sun.

The CTC believes good public relations and education regarding psychiatry and mental illness should be prime concerns of the College. We should not leave a vacuum of information and overt concern which is then filled by misinformation which in turn reinforces the stigma of mental illness and psychiatric treatment. ${ }^{4.5}$ The report of the CTC Working Party considering this subject will soon be submitted to the Bulletin.

\section{The CTC}

The Committee believed, and the editors of the Bulletin have agreed, that a regular report on the activities of the CTC would be informative. Trainees will learn what the CTC is doing on their behalf and may therefore respond 
with suggestions or disagreements. Any comments or suggestions can be made to your divisional representative or the officers of the CTC through the College.

The Committee would also welcome greater competition in the elections to the CTC. It is quite often the case that not enough trainees stand for an election to be necessary. Elections are held every two years in each division; Inceptors are as eligible as members.

Peter White

Chairman

Collegiate Trainees' Committee
REFERENCES

${ }^{1}$ Department of Health and Social Security, Joint Consultants Committee, Chairmen of regional health authorities (1986) Hospital medical staffing: achieving a balance. London: DHSS.

${ }^{2}$ British Medical Journal (1987) Manpower package 'welcomed' by 80 votes to 75. British Medical Journal, 294, 66-68.

${ }^{3}$ KINGDON, D. G. \& SzULECKA, T. K. (1986) Establishing a distinct psychiatric service without psychiatric trainees. Bulletin of The Royal College of Psychiatrists, 10, 338-340.

'TURNER, T. H. (1986) Whatever happened to stigma? Bulletin of the Royal College of Psychiatrists, 10, 8-9.

${ }^{5}$ Morrison, A. (1985)-Psychiatry in decline-A personal view. Bulletin of The Royal College of Psychiatrist, 9, 4-7.

\section{Notes of Guidance for Representatives on Advisory (Consultant) Appointments Committees}

The Notes of Guidance, published in the Bulletin (August $1986,10,200-201$ ) drew the attention of College representatives to questions of racial and sexual discrimination and health as follows:

Employers in the United Kingdom and Eire are required by law not to discriminate on grounds of race or of sex against their employees or their candidates for employment. The College representative is expected to insist that this principle is at all time scrupulously observed during the proceedings of the Committee.

Service on an Advisory Appointments Committee may possibly result in its members having to appear before a Tribunal in a race or sex discrimination case. It would be prudent for members to make and keep in their own possession notes about the candidates and the proceedings of the Committee if such an appeal seems at all likely. If a representative is in any way concerned that there has been an irregularity in the proceedings of the Appointment Committee he should notify the President of the College.

It is not the task of the Appointments Committee to make a judgment on the physical or mental health of a candidate. If, however, serious doubt regarding health does arise during the course of an interview, the College Assessor should apply the usual criteria of suitability and may wish to make a recommendation for appointment subject to satisfactory medical examination.

The Court of Electors recently affirmed that this guidance should apply not only to Consultant appointments but also both to Senior Registrar appointments (where the College representative-usually the Regional Adviser or his/her nominee-would be present) and to the appointment of all other grades of medical staff, when Members of the College should ensure that the Guidelines are scrupulously observed.

\section{Special Committee on Unethical Psychiatric Practices}

At the recommendation of the Special Committee on the Political Abuse of Psychiatry, Council has agreed to revise the remit of that body and it will now be empowered to deal with all aspects of unethical psychiatric practices, throughout the world, when it is clear that the College should, as a matter of principle, voice its concern.

In accordance with this recommendation, the title of the Special Committee has now been changed to Special Committee on Unethical Psychiatric Practices.

Council endorsed Professor Ken Rawnsley as the new Chairman of the Special Committee and expressed its appreciation of the work undertaken by Dr Peter Sainsbury, both in public and behind the scenes, during the eight years he was Chairman of the Special Committee on the Political Abuse of Psychiatry.

\section{Repeat of Christmas Lecture}

Due to the success of the College's first Christmas Lecture for Young People, Professor Anthony Clare has agreed to give a repeat of this lecture entitled 'Aren't We All a Little Mad?' on Friday, 3 April 1987 at 3.00 p.m. at the Royal
Society, 6 Carlton House Terrace, London SW1. Applications for tickets must be made in advance and are available from Deborah Hart, Royal College of Psychiatrists, 17 Belgrave Square, London SWIX 8PG. 